\title{
Flaxseed Oil and Lipoprotein (a) Significantly Increase Bleeding Time in Type 2 Diabetes Patients in Cape Breton, Nova Scotia, Canada
}

\author{
D.E. Barre * , O. Griscti, K.A. Mizier-Barre and K. HAfez \\ Department of Biology, University College of Cape Breton \\ (P.O. Box 5300, Sydney, Nova Scotia, B1P-6L2 CANADA)
}

Edited by T. Itoh, Kitasato Univ., and accepted February 4, 2005 (received for review October 12, 2004)

\begin{abstract}
Platelet hyper-aggregation is a serious manifestation of type 2 diabetes and a precipitating factor in the most frequent cause of death in type 2 diabetes-myocardial infarction. Consumption of flaxseed oil as a dietary supplement containing alpha-linolenic acid (ALA, 18:3 n-3) through its metabolism to eicosapentaenoic acid (EPA, 20:5 n-3) and subsequent production of anti-aggregatory eicosanoids may reduce such aggregation in vivo. Lp (a) may also influence platelet aggregation in vivo. Furthermore, serum Lp(a) concentrations are increased and bleeding time is decreased in type 2 diabetics presenting an enhanced risk of myocardial infarction. It was hypothesised that $\mathrm{Lp}(\mathrm{a})$ and bleeding time would be correlated due to the considerable molecular homology between apolipoprotein (a) and plasminogen which should decrease bleeding time. Bleeding time is an excellent measure of in vivo platelet aggregability. One purpose of this study was to determine the impact flaxseed oil consumption on bleeding time compared to those on safflower oil and to determine the impact of $\mathrm{Lp}(\mathrm{a})$ on bleeding time. It was a secondary purpose to determine if there were any gender differences pre- or pre-post treatment in bleeding time. Subjects $(\mathrm{N}=40)$ were randomly divided to take either the treatment, flaxseed oil $(\mathrm{N}=20)$ or the placebo, safflower oil $(\mathrm{N}=20)$. Each of the treatment or placebo groups contained equal numbers of males $(\mathrm{N}=10)$ and females $(\mathrm{N}=10)$. Some subjects dropped from the study due to reasons not related to treatment side effects. Subjects came for 3 visits, each 3 months apart. On each visit age, gender and BMI were recorded and bleeding time was performed. At the completion of visit 2 , subjects were randomly assigned to take 1 gram of oil per $10 \mathrm{~kg}$ body weight each day for 3 months. Comparing pre- and post-treatment, there was a statistically significant increase in bleeding time in the flaxseed oil group including each of males and females while there was no change in the safflower group in total or by gender. Males had a statistically shorter bleeding time pre-treatment while males and females showed no difference post-treatment with flaxseed oil consumption. Males and females showed a non-significant correlation and statistically significant correlation respectively between pre-treatment values for Lp(a) and bleeding time. The statistically significant correlation also held for the whole population though at a lower value than females. It is concluded that flaxseed oil consumption has a statistically significant effect on slowing bleeding time thus likely reducing the risk of myocardial infarction and that such effect is more profound in males than females suggesting a greater efficacy of flaxseed oil administration for type 2 diabetic males. It is concluded that type
\end{abstract}

\footnotetext{
${ }^{*}$ Correspondence to: D.E. BARRE, Department of Biology, University College of Cape Breton, P.O. Box 5300, Sydney, Nova Scotia, B1P-6L2 CANADA

E-mail: edbarre@ns.sympatico.ca
} 
2 diabetic females take better advantage of elevated $\mathrm{Lp}(\mathrm{a})$ concentrations than do males thus, at least in part rendering the impact of flaxseed oil on bleeding time greater in males.

Key words: type 2 diabetes, platelet, lipoprotein (a), bleeding time, gender

\section{Introduction}

Type 2 diabetics usually die from atherosclerosis, a significant feature of which is the formation of thrombi and/or emboli $(1,2)$. The ability of platelets to clot is reflected in the bleeding time $(3,4)$. Type 2 diabetes features platelet hyperaggregation $(5,6)$. Type 2 diabetics are frequently placed on various therapeutic regimes intended to reduce platelet aggregation $(7,8)$. Reduced in vitro platelet aggregation has not been observed in some persons taking flaxseed oil $(9,10)$ though in other studies the impact of increased dietary ALA suggests a decreased platelet function(11-13); however flaxseed oil has never been tried in type 2 diabetics in an attempt to manipulate platelet aggregation. Flaxseed oil contains alpha-linolenic acid (ALA, 18:3 n-3) which is metabolized in part to eicosapentaenoic acid (EPA, 20:5 n-3) $(14,15)$. Upon agonist stimulation of platelets, EPA produces prostaglandin $\mathrm{E}_{3}\left(\mathrm{PGE}_{3}\right)$ and prostaglandin $\mathrm{I}_{3}\left(\mathrm{PGI}_{3}\right)$, both of which reduce platelet aggregation and prolong bleeding time $(16,17)$. EPA also reduces the arachidonic acid (AA, 20:4 n-6) content of platelets thus reducing the AA- derived proaggregatory eicosanoids, thromboxane $\mathrm{A}_{2}\left(\mathrm{TxA}_{2}\right)$ and prostaglandin $\mathrm{E}_{2}\left(\mathrm{PGE}_{2}\right)$ produced upon agonist stimulation of platelets $(18,19)$. It was hypothesized that a dietary supplement of flaxseed oil rich in ALA would prolong bleeding time in type 2 diabetics. The objective of this study was to determine if a dietary supplement of flaxseed oil delivering an average of $60.0 \pm 0.4 \mathrm{mg}$ of ALA per kg body weight/day for 3 months would significantly lengthen bleeding time in type 2 diabetics. It was a secondary objective to determine if there were significant differences in bleeding time between males and females before flaxseed oil administration and if the impact of flaxseed oil was significantly different in male versus female type 2 diabetics.

It was also of interest to know what impact if any occurred on the bleeding time as the result of $\mathrm{Lp}(\mathrm{a})$ potentially mediated gender differences before treatment. Lipoprotein (a) blood plasma concentrations are elevated in type 2 diabetics $(20,21)$. Such elevation results in an enhanced risk of atherosclerosis $(22,23)$.
This elevated risk is due to increased lipid influx into the arterial wall (24), perturbation of the arterial endothelium (25) and a considerable homology between apolipoprotein (a) in $\mathrm{Lp}(\mathrm{a})$ and plasminogen $(26,27)$. This homology is believed to interfere with the binding of plasminogen to the fibrin holding the embolus or thrombus together $(28,29)$, thus reducing the activity of plasmin $(30,31)$. Plasmin breaks down the fibrin thus reducing the residency time of embolus or thrombus and consequently decreasing the risk of a myocardial infarction $(32,33)$. However, previous studies (34-38) suggest that there is a negative correlation between platelet reactivity in vitro and $\mathrm{Lp}$ (a) concentrations based on competitive displacement of fibrinogen from the IIb protein on the fibrinogen (GPIIb/IIIa) receptor on agonist-stimulated platelets and manipulation of platelet c-AMP concentrations by Lp(a). On the contrary, a number of authors have shown an increased $(39,40)$ or no change $(41)$ in in vitro platelet reactivity upon incubation with increasing concentration of $\mathrm{Lp}(\mathrm{a})$. However the correlation between blood serum concentrations of $\mathrm{Lp}(\mathrm{a})$ and bleeding time has never been published. It was hypothesized that while elevated Lp(a) concentrations would present a enhanced risk of atherosclerosis in terms of increased lipid influx into the arterial wall and potential interference with plasmin activity, they may also modify platelet reactivity in vivo type 2 diabetics. Such modification may help offset the impact of elevated $\mathrm{Lp}$ (a) concentrations in terms of increased embolus or thrombus residence time.

\section{Methods}

Subjects ( $\mathrm{n}=20$ male, 20 female) were randomly chosen from among 84 Caucasians responding in approximately equal sex numbers to a Sydney, Nova Scotia newspaper advertisement and two area physicians. The inclusion criteria were 18 years of age or older, diagnosed type 2 diabetic for longer than six months and with well controlled blood glucose levels, while the exclusion criteria were: not meeting the inclusion criteria, pregnant or planning on becoming pregnant during the clinical trial, involved in an athletic 
training programme and/or taking insulin or any omega 3 supplement. Subjects were randomly assigned in equal gender numbers to receive flaxseed oil or the placebo, safflower oil. Regarding hypolipidaemic medications, subjects were evenly distributed among the four groups. This study received approval from the University College of Cape Breton Human Ethics Review Committee.

Subjects came for 3 visits, each 3 months apart. On visit 1 their age, sex and body mass index were recorded and bleeding time were performed. On visit 2, measures identical to visit 1 was performed. At the completion of visit 2 subjects were randomly assigned to receive 1 gram of oil(flaxseed(treatment) or safflower(placebo) per $10 \mathrm{~kg}$ body weight and instructed to consume the oil for 3 months until the evening before visit 3. Fatty acid composition of the oils was determined by gas liquid chromatography. Bleeding time was measured via the Ivy bleeding time (42) using the Simplate II R device and following the manufacturer's (Organon Teknika, Durham, North Carolina, USA) directions.

\section{Statistical Analyses}

The data in Tables $\mathbf{2}$ and $\mathbf{3}$ was analysed by a one way analysis of variance while the data in Table 4 was analysed by a two way analysis of variance. Individual differences were determined by a Tukey's test. Pearson correlations were done to determine the degree of relation between serum $\mathrm{Lp}$ (a) concentrations and bleeding time (Table 5). Statistical significance was $\mathrm{p}<0.05$.

\section{Results}

The composition of the oils is shown in Table 1. Levels of oil and alpha-linolenic acid consumption are listed in Table 2. Subject baseline characteristics (visits 1 and 2) are contained in Table 3. Pre-treatment bleeding time data is found in Table 4 and 5. Males had statistically significant shorter bleeding time before treatment than females. For all subjects or for males or females comparing visits 1 and 2 there was no significant difference in bleeding time. At the end of flaxseed oil treatment males did not have significantly different bleeding time compared to females. Safflower oil was without effect on bleeding time for males and females combined or considered separately (Table 6). Conse- quently males were still significantly lower in bleeding time compared to females when both had completed the

Table 1 Fatty Acid Composition (Weight Percent i.e. mg of an Individual Fatty Acid per 100 mg of Fatty Acids) of Flaxseed Oil (Treatment) and Safflower Oil (placebo). Data is reported as mean for five selected capsules of each oil type.

\begin{tabular}{|l|c|c|}
\hline Fatty acid & Flaxseed oil & Safflower oil \\
\hline $14: 0$ & - & 0.2 \\
\hline $16: 0$ & 5.6 & 6.3 \\
\hline $18: 0$ & - & 2.2 \\
\hline $18: 1 \mathrm{n}-9$ & 15.1 & 14.1 \\
\hline $18: 2 \mathrm{n}-6$ & 14.6 & 74.2 \\
\hline $18: 3 \mathrm{n}-3$ & 57.2 & $<0.1$ \\
\hline $20: 4 \mathrm{n}-6$ & - & - \\
\hline $20: 5 \mathrm{n}-3$ & - & - \\
\hline $22: 6 \mathrm{n}-3$ & - & - \\
\hline
\end{tabular}

Table 2 Average Oil Consumption (grams/day and $\mathrm{mg} / \mathrm{kg}$ body weight/day) and Alpha-Linolenic Acid Consumption (grams/day and $\mathrm{mg} / \mathrm{kg}$ body weight/day).

Average oil consumption (grams/day)

\begin{tabular}{|l|r|r|}
\hline & Flaxseed oil & Safflower oil \\
\hline Male & $9.8 \pm 0.3$ & $9.7 \pm 0.4$ \\
\hline Female & $9.4 \pm 0.3$ & $9.2 \pm 0.1$ \\
\hline
\end{tabular}

Average oil consumption ( $\mathrm{mg} / \mathrm{kg}$ body weight/day)

\begin{tabular}{|l|c|c|}
\hline & Flaxseed oil & Safflower oil \\
\hline Male & $103.8 \pm 0.7$ & $103.0 \pm 1.5$ \\
\hline Female & $106.7 \pm 0.9$ & $103.4 \pm 0.8$ \\
\hline
\end{tabular}

Average alpha-linolenic acid consumption (grams/day)

\begin{tabular}{|l|c|c|}
\hline & Flaxseed oil & Safflower oil \\
\hline Male & $5.3 \pm 0.2$ & $<0.01$ \\
\hline Female & $5.5 \pm 0.2$ & $<0.01$ \\
\hline
\end{tabular}

Average alpha-linolenic acid consumption ( $\mathrm{mg} / \mathrm{kg}$ body weight/day)

\begin{tabular}{|l|c|c|}
\hline & Flaxseed oil & Safflower oil \\
\hline Male & $59.2 \pm 0.4$ & $<0.01$ \\
\hline Female & $60.8 \pm 0.5$ & $<0.01$ \\
\hline
\end{tabular}


Table 3 Pre-Treatment Characteristics of Subjects (all Caucasian). Data $(\mathrm{N}=32)$ is reported as mean \pm standard error of the mean (S.E.M.) for the subjects who completed the trial. Statistically significant differences are marked with a superscript letter with different letters representing a statistically significant difference across a row.

\begin{tabular}{|l|c|c|c|c|c|c|c|}
\hline & $\begin{array}{c}\text { All } \\
\text { subjects }\end{array}$ & $\begin{array}{c}\text { All } \\
\text { males }\end{array}$ & $\begin{array}{c}\text { All } \\
\text { females }\end{array}$ & $\begin{array}{c}\text { Flaxseed } \\
\text { males }\end{array}$ & $\begin{array}{c}\text { Flaxseed } \\
\text { females }\end{array}$ & $\begin{array}{c}\text { Safflower } \\
\text { males }\end{array}$ & $\begin{array}{c}\text { Safflower } \\
\text { females }\end{array}$ \\
\hline Age (years) & $59.5 \pm 1.7$ & $60.7 \pm 2.9$ & $58.3 \pm 1.7$ & $57.9 \pm 4.4$ & $56.6 \pm 2.6$ & $64.6 \pm 3.0$ & $60.8 \pm 1.1$ \\
\hline $\begin{array}{l}\text { Sex (M/F) } \\
\mathrm{N}=\end{array}$ & 32 & 18 & 14 & 10 & 8 & 8 & 6 \\
\hline $\begin{array}{l}\text { Body mass } \\
\text { index (BMI) } \\
\mathrm{kg} / \mathrm{m}^{2} \\
\text { visit 1 }\end{array}$ & $32.4 \pm 0.9$ & $30.3 \pm 0.7$ & $33.7 \pm 1.6$ & $30.9 \pm 1.2$ & $33.5 \pm 1.8$ & $29.5 \pm 0.5$ & $33.0 \pm 2.6$ \\
\hline $\begin{array}{l}\text { Body mass } \\
\text { index (BMI) } \\
\mathrm{kg} / \mathrm{m}^{2} \\
\text { visit 2 }\end{array}$ & $32.2 \pm 1.0$ & $30.3 \pm 0.8$ & $33.4 \pm 1.7$ & $30.6 \pm 1.2$ & $33.6 \pm 2.0$ & $29.8 \pm 0.8$ & $33.4 \pm 2.6$ \\
\hline
\end{tabular}

Table 4 Bleeding Time in Seconds Measured at Visits 1 and 2 (Prior to Treatment or Placebo Administration). Data $(\mathrm{N}=32)$ is reported as mean \pm standard error of the mean (S.E.M.) for the subjects who completed the trial. Statistically significant ( $p$ $<0.05$ ) differences are marked with a superscript representing a statistically significant difference across a row. One or more shared superscripts signify a lack of significant difference.

\begin{tabular}{|c|c|c|c|c|c|}
\hline $\begin{array}{c}\text { All subjects } \\
\text { visit } 1\end{array}$ & $\begin{array}{c}\text { All subjects } \\
\text { visit 2 }\end{array}$ & $\begin{array}{c}\text { All males } \\
\text { visit } 1\end{array}$ & $\begin{array}{c}\text { All males } \\
\text { visit 2 }\end{array}$ & $\begin{array}{c}\text { All females } \\
\text { visit 1 }\end{array}$ & $\begin{array}{c}\text { All females } \\
\text { visit 2 }\end{array}$ \\
\hline $\mathrm{N}=32$ & $\mathrm{~N}=32$ & $\mathrm{~N}=18$ & $\mathrm{~N}=18$ & $\mathrm{~N}=14$ & $\mathrm{~N}=14$ \\
\hline $219.3 \pm 25.6$ & $225.4 \pm 27.2$ & $204.3 \pm 17.2$ & $208.5 \pm 18.2$ & $234.7 \pm 21.3^{\mathrm{a}}$ & $243.6 \pm 23.3^{\mathrm{a}}$ \\
\hline
\end{tabular}

Table 5 Average Bleeding Time in Seconds Measured for Visits 1 and 2 (Prior to Treatment or Placebo Administration) and Visit 3. Data $(\mathrm{N}=32)$ is reported as mean \pm standard error of the mean (S.E.M.) for the subjects who completed the trial. Statistically significant $(\mathrm{p}<0.05)$ differences are marked with a superscript representing a statistically significant difference across a row or down a column. One or more shared superscripts signify a lack of significant difference.

\begin{tabular}{|l|l|l|l|}
\hline $\begin{array}{l}\text { Flaxseed males -visit 1 } \\
\mathrm{N}=10\end{array}$ & $206.2 \pm 13.7$ & $\begin{array}{l}\text { Safflower males-visit 1 } \\
\mathrm{N}=8\end{array}$ & $203.7 \pm 40.7$ \\
\hline $\begin{array}{l}\text { Flaxseed males-visit } 2 \\
\mathrm{~N}=10\end{array}$ & $211.4 \pm 17.1$ & $\begin{array}{l}\text { Safflower males-visit 2 } \\
\mathrm{N}=8\end{array}$ & $204.6 \pm 37.2$ \\
\hline $\begin{array}{l}\text { Flaxseed females-visit 1 } \\
\mathrm{N}=8\end{array}$ & $238.3 \pm 18.4^{\mathrm{a}}$ & $\begin{array}{l}\text { Safflower females-visit 1 } \\
\mathrm{N}=6\end{array}$ & $230.0 \pm 29.8^{\mathrm{a}}$ \\
\hline $\begin{array}{l}\text { Flaxseed females-visit 2 } \\
\mathrm{N}=8\end{array}$ & $249.2 \pm 22.6^{\mathrm{a}}$ & $\begin{array}{l}\text { Safflower females-visit 2 } \\
\mathrm{N}=6\end{array}$ & $238.0 \pm 30.8^{\mathrm{a}}$ \\
\hline
\end{tabular}


Table 6 Bleeding Time (seconds) Average of Visits 1 and 2 versus Visit 3 to Treatment or Placebo. Data $(\mathrm{N}=32)$ is reported as mean \pm standard error of the mean (S.E.M.) for the subjects who completed the trial. Statistically significant differences are marked with a superscript letter with different letters representing a statistically significant difference across a row or column. Values are statistically identical if they share one or more superscripts across a row or column. One or more shared superscripts signify a lack of significant difference.

\begin{tabular}{|l|l|l|l|}
\hline $\begin{array}{l}\text { Flaxseed-all subjects } \\
\text { average of visits } 1 \text { and } 2 \\
\mathrm{~N}=18\end{array}$ & $226.3 \pm 9.9^{\mathrm{a}}$ & $\begin{array}{l}\text { Safflower-all subjects } \\
\text { average of visits } 1 \text { and } 2 \\
\mathrm{~N}=14\end{array}$ & $219.7 \pm 17.7^{\mathrm{a}}$ \\
\hline $\begin{array}{l}\text { Flaxseed-all subjects } \\
\text { visit } 3 \\
\mathrm{~N}=18\end{array}$ & $311.2 \pm 16.6^{\mathrm{b}}$ & $\begin{array}{l}\text { Safflower-all subjects } \\
\text { visit 3 } \\
\mathrm{N}=14\end{array}$ & $230.3 \pm 24.1^{\mathrm{a}}$ \\
\hline $\begin{array}{l}\text { Flaxseed males average } \\
\text { of visits } 1 \text { and } 2 \\
\mathrm{~N}=10\end{array}$ & $208.8 \pm 10.7^{\mathrm{c}}$ & $\begin{array}{l}\text { Safflower males average } \\
\text { of visits } 1 \text { and } 2 \\
\mathrm{~N}=8\end{array}$ & $204.2 \pm 21.4^{\mathrm{c}}$ \\
\hline $\begin{array}{l}\text { Flaxseed males } \\
\text { visit } 3 \\
\mathrm{~N}=10\end{array}$ & $298.3 \pm 19.7^{\mathrm{b}, \mathrm{d}}$ & $\begin{array}{l}\text { Safflower males } \\
\text { visit 3 } \\
\mathrm{N}=8\end{array}$ & $219.3 \pm 20.4^{\mathrm{a}}$ \\
\hline $\begin{array}{l}\text { Flaxseed females } \\
\text { average of visits } 1 \text { and } 2 \\
\mathrm{~N}=8\end{array}$ & $243.4 \pm 14.4^{\mathrm{e}}$ & $\begin{array}{l}\text { Safflower females } \\
\text { average of visits } 1 \text { and } 2 \\
\mathrm{~N}=6\end{array}$ & $234.3 \pm 20.4^{\mathrm{a}, \mathrm{e}}$ \\
\hline $\begin{array}{l}\text { Flaxseed females } \\
\text { visit 3 } \\
\mathrm{N}=8\end{array}$ & $327.3 \pm 28.5^{\mathrm{b}, \mathrm{f}}$ & $\begin{array}{l}\text { Safflower females } \\
\text { visit 3 } \\
\text { N=6 }\end{array}$ & $241.2 \pm 23.2^{\mathrm{a}, \mathrm{e}}$ \\
\hline
\end{tabular}

safflower placebo. Bleeding time and Lp(a) data and their respective correlations are found in Table 7. There were no statistically significant differences in $\mathrm{Lp}(\mathrm{a})$ concentrations or bleeding time between visits 1 and 2 for a given gender or for all subjects combined. In terms of gender, only females showed a statistically significant correlation between $\mathrm{Lp}$ (a) concentrations and bleeding time, pre-treatment. However, when all subjects were assessed there was still a statistically significant correlation between $\mathrm{Lp}(\mathrm{a})$ concentrations and bleeding time.

\section{Discussion and Conclusion}

Bleeding time is an accurate measure of in vivo platelet aggregation $(3,4)$. Platelet hyper-aggregation plays a significant role in myocardial infarction in type 2 diabetics $(5,6)$. Such aggregation results in the formation of thrombi and/or emboli which contribute significantly to the reduction of blood flow to the myocardium. Such reductions in blood flow result in decreased oxygen tension in the myocardium. When the myocardium is compromised, tissue death (myocardial infarction) results. Males had a much shorter bleeding time compared to females before the administration of either oil. This is the first comparison of male versus female bleeding time in type 2 diabetics. However, the overall bleeding time data are similar to the literature $(43,44)$. The absence of significant differences in males and females in $\mathrm{Lp}$ (a) concentrations suggest that the longer pre-treatment bleeding time seen in females are due to a stronger effect of $\mathrm{Lp}$ (a) than in males (Table 5). In females about 50 percent of the variability in platelet aggregation may be attributed to $L p(a)$ concentrations while in males it is only about one percent. The reason for this is not clear but it would appear that other factors affecting platelet aggregation, such as platelet membrane fatty acid composition and subsequent balance between fatty acid derived pro- and anti-aggregatory eicosanoids basally or in the platelet-stimulated 
Table 7 Bleeding Time in Seconds, Serum Lp(a) Concentrations in $\mathrm{mg} / \mathrm{dl}$ and Pearson Correlations between Bleeding Time and $\mathrm{Lp}(\mathrm{a})$ Concentrations. Data $(\mathrm{N}=32)$ is reported as mean \pm standard error of the mean (S.E.M.) for the subjects who completed the trial. Statistically significant differences are marked with a superscript letters with different letters representing a statistically significant difference across a row. One or more shared superscripts signify a lack of significant difference.

\begin{tabular}{|c|c|c|c|c|c|c|}
\hline Parameter & $\begin{array}{l}\text { All subjects } \\
\text { visit } 1\end{array}$ & $\begin{array}{c}\text { All subjects } \\
\text { visit } 2\end{array}$ & $\begin{array}{l}\text { All males } \\
\text { visit } 1\end{array}$ & $\begin{array}{l}\text { All males } \\
\text { visit } 2\end{array}$ & $\begin{array}{l}\text { All females } \\
\text { visit } 1\end{array}$ & $\begin{array}{c}\text { All females } \\
\text { visit } 2\end{array}$ \\
\hline $\mathrm{N}$ & $\mathrm{N}=32$ & $\mathrm{~N}=32$ & $\mathrm{~N}=18$ & $\mathrm{~N}=18$ & $\mathrm{~N}=14$ & $\mathrm{~N}=14$ \\
\hline $\begin{array}{l}\text { Bleeding time } \\
(\mathrm{sec})\end{array}$ & $242.3 \pm 25.6^{\mathrm{a}}$ & $247.4 \pm 27.2^{\mathrm{a}}$ & $220.3 \pm 17.2^{\mathrm{b}}$ & $223.5 \pm 18.2^{b}$ & $264.7 \pm 21.3^{\mathrm{a}, \mathrm{c}}$ & $271.6 \pm 23.3^{\mathrm{a}, \mathrm{c}}$ \\
\hline $\begin{array}{l}\mathrm{Lp}(\mathrm{a}) \\
\text { concentrations } \\
\mathrm{mg} / \mathrm{dl}\end{array}$ & $11.3 \pm 4.1$ & $12.5 \pm 4.5$ & $9.5 \pm 3.7$ & $9.1 \pm 3.9$ & $13.1 \pm 7.4$ & $8.9 \pm 8.6$ \\
\hline $\begin{array}{l}\text { Pearson } \\
\text { correlation } \\
\text { between } \\
\text { bleeding time } \\
\text { and Lp(a) } \\
\text { concentration }\end{array}$ & $0.51^{\mathrm{a}, \mathrm{b}}$ & $0.54^{\mathrm{a}, \mathrm{b}}$ & $0.09^{\mathrm{c}}$ & $0.11^{\mathrm{c}}$ & $0.74^{\mathrm{a}, \mathrm{d}}$ & $0.72^{\mathrm{a}, \mathrm{d}}$ \\
\hline
\end{tabular}

state (45) may provide an explanation. In females, the current data is consistent with previous work (34-38) suggesting reduced platelet reactivity in vitro with increasing $\mathrm{Lp}$ (a) concentrations based on competitive displacement of fibrinogen from the IIb protein on the fibrinogen (GPIIb/IIIa) receptor on agonist-stimulated platelets and subsequent elevation of platelet c-AMP concentrations by $\operatorname{Lp}(\mathrm{a})$. This data is validated by its consistency between visits 1 and 2 for males or females alone or the genders combined.

The difference in bleeding time made males more amenable to changed bleeding time. Reasons for shorter bleeding time in males may have included higher levels of AA content in platelet phospholipid membranes and/or a greater efficiency of conversion of AA to AAderived pro-aggregatory eicosanoids. It could also be that other factors favouring platelet aggregation predominate in males.

The increase in bleeding time was most likely due to the fact that flaxseed oil contains ALA which is metabolized in part, upon consumption by type 2 diabetic humans, to EPA $(14,15)$. ALA is the only fatty acid present in such large amounts in flaxseed oil compared to only the trace amounts found in safflower oil. Fur- thermore when platelets are stimulated by agonists, EPA in the platelet membrane produces $\mathrm{PGE}_{3}$ and $\mathrm{PGI}_{3}$, both of which reduce platelet aggregation and prolong bleeding time $(16,17)$. Increases in platelet membrane EPA also reduces the AA, content of platelets thus reducing the AA-derived proaggregatory eicosanoids, $\mathrm{TxA}_{2}$ and $\mathrm{PGE}_{2}$ produced upon agonist stimulation of platelets $(18,19)$. It may be that males are more amenable to the accumulation of EPA in the phospholipids of the platelet membrane and/or EPA's metabolism to anti-aggregatory eicosanoids. It may also be that if males have a greater EPA accumulation in platelet membrane phospholipids, then AA levels in the same are more dramatically reduced thus more significantly reducing the AA-derived pro-aggregatory eicosanoids. It could also be that flaxseed oil administration slows the molar efficiency of AA transformation into AA derived pro-aggregatory eicosanoids. The effect of the flaxseed oil must have been due its ALA content since that was the only fatty acid which is not present in the safflower oil.

The results are valid as there was no statistically difference between visits 1 and 2 for all subjects or for females or males separately when comparing visits 1 
and 2. Furthermore, the results are valid because male bleeding times were not statistically significantly different comparing flaxseed versus safflower groups with the same applying to females.

The effects of the flaxseed oil were without reported side-effects. All patients completing the trial were compliant with requests made of them.

It is concluded that male bleeding time is shorter than female bleeding time prior to treatment. The shorter bleeding time for males is more amenable to lengthening than with female subjects though both sexes significantly lengthened their bleeding time. Thus the usefulness of flaxseed oil may be greater in males than in females in terms of reducing the ability of platelets to contribute to the risk of myocardial infarction. It is also concluded that the effect of the flaxseed oil on bleeding is due to the alpha-linolenic content of flaxseed oil. It is further concluded that $\mathrm{Lp}(\mathrm{a})$ significantly reduces bleeding time in female but not male type 2 diabetics with a significant correlation existing in the entire population. The most likely explanation is a dominating effect of competitive displacement of fibrinogen from the IIb protein of the GPIIb/IIIa receptor by $\mathrm{Lp}(\mathrm{a})$ in females and subsequent elevation of platelet c-AMP concentrations but not so with significant impact in males. Thus the impact of alpha-linolenic acid impact on platelet aggregation in males is greater due, at least in part as the result of the insignificant impact of $L p(a)$ on bleeding time.

\section{Acknowledgments}

Ms. Pat Collins, R.N. of the University College of Cape Breton Health Centre is thanked for helping with blood taking and anthropometric measures. The authors also acknowledge the contribution of Dr. J. Wawrzyszyn of Sydney for drawing this study to the attention of his patients. We also thank Dr. E. Rudiuk of the University College of Cape Breton for his assistance with statistical analyses. The flaxseed and safflower oil capsules were the generous gift of Bioriginal Food and Science Corporation, Saskatoon, Saskatchewan S7J 0R7 Canada.

\section{Reference}

1. P. FERRONI, S. BASILI, A. FALCO and G. DAVI, Platelet Activation in Type 2 Diabetes Mellitus, J. Thromb. Haemost.,
Vol. 2, 1282-1291 (2004).

2. C. PACKARD and A.G. OLSSON, Management of Hypercholesterolaemia in the Patient with Diabetes, Int. J. Clin. Pract. Suppl., Vol. 130, 27-32 (2002).

3. R.P.C. RODGERS and J. LEVIN, A Critical Reappraisal of the Bleeding Time, Semin. Thromb. Haemostasis, Vol. 16, 1-20 (1990).

4. JR. O'BRIEN, The Bleeding Time in Normal and Abnormal Subjects, J. Clin Pathol., Vol. 4, 272-285 (1951).

5. J. SAGEL, J.A. COLWELL, L. CROOK and M. LAIMINS, Increased Platelet Aggregation in Early Diabetes Mellitus, Ann. Intern. Med., Vol. 82, 733-738 (1975).

6. S. MANDAL, R. SARODE, S. DASH and R.J. DASH, Hyperaggregation of Platelets Detected by Whole Blood Platelet Aggregometry in Newly Diagnosed Noninsulin-Dependent Diabetes Mellitus, Am. J. Clin. Pathol., Vol. 100, 103-107 (1993).

7. L. HANSSON, A. ZANCHETTI, S. WESTERLING et al., Effects of Intensive Blood-Pressure Lowering and Low-Dose Aspirin in Patients with Hypertension: Principal Results of the Hypertension Optimal Treatment (HOT) Randomised Trial. HOT Study Group, Lancet, Vol. 351, 1755-1762 (1998).

8. J.A. COLWELL, Aspirin Therapy in Diabetes (Technical Review), Diabetes Care, Vol. 20, 1767-1771 (1997).

9. J.K. CHAN, B.E. McDONALD, J.M. GERRARD, V.M. BRUCE, B.J. WEAVER and B.J. HOLUB, Effect of Dietary Alpha-Linolenic Acid and Its Ratio to Linoleic Acid on Platelet and Plasma Fatty Acids and Thrombogenesis, Lipids, Vol. 28, 811-817 (1993).

10. D.S. KELLEY, G.J. NELSON, J.E. LOVE, L.B. BRANCH, P.C. TAYLOR, P.C. SCHMIDT, B.E. MACKEY and J.M. IACONO, Dietary Alpha-Linolenic Acid Alters Tissue Fatty Acid Composition, but not Blood Lipids, Lipoproteins or Coagulation Status in Humans, Lipids, Vol. 28(6), 533-537 (1998).

11. S. RENAUD, R. MORAZAIN, F. GODSEY et al., Nutrients, Platelet Function and Composition in Nine Groups of French and British farmers, Atherosclerosis, Vol. 60, 37-48 (1986).

12. S. RENAUD, F. GODSEY, E. DUMONT, C. THEVENON, E. ORTCHANIAN and J.L. MARTIN, Influence of Long-Term Diet Modification on Platelet Function and Composition in Moselle Farmers, Am. J. Clin. Nutr., Vol. 43, 136-150 (1986).

13. M.A. ALLMAN, M.M. PENA and D. PANG, Supplementation with Flaxseed Oil versus Sunflowerseed Oil in Healthy Young Men Consuming a Low Fat Diet: Effects on Platelet Composition and Function, Eur. J. Clin. Nutr., Vol. 49, 169-178 (1995).

14. A.P. SIMOPOULOS, Essential Fatty Acids in Health and Chronic Disease, Am. J. Clin. Nutr., Vol. 70, 560S-569S (1999).

15. A.P. SIMOPOULOS, Omega 3 Fatty Acids in Health and Disease and in Growth and Development, Am. J. Clin. Nutr., Vol. 54, 438-463 (1991)

16. B.J. HOLUB, Clinical Nutrition: 4. Omega 3 Fatty Acids in Cardio vascular Disease, CMAJ, Vol. 166, 608-615 (2002).

17. E.A. EMKEN, R.O. ADLOF and R.M. GULLEY, Dietary Linoleic Acid Influences Desaturation and Acylation of Deuterium-Labelled Linoleic Acids in Young Adult Males, Biochim. 


\section{D.E. Barre, O. Griscti, K.A. Mizier-Barre et al.}

Biophys. Acta, Vol. 1213, 277-288 (1994)

18. M. HAMBERG, J. SVENSSON and B. SAMUELSSON, Thromboxanes: a New Group of Biologically Active Compounds Derived Ferom Prostaglandin Endoperoxides, Proc. Natl. Acad. Sci. USA, Vol. 72, 2994-2998 (1975).

19. G. RAJTAR, C. CERLETTI, M.N. CASTAGNOLI, V. BERTERLE and G. deGAETANO, Biochem. Pharm., Vol. 34, 307-310 (1985).

20. D.D. LABUDOVIC, K.N. TOSEKA, S.B. ALABAKOVSKA, B. TODORVA, Apoprotein (a) Phenotypes and Plasma Lipoprotein (a) in Patients with Diabetes Mellitus, Clin. Biochem., Vol. 36, 545-551 (2003).

21. S.S. HABIB and M. ASLAM, Lipids and Lipoprotein(a) Concentrations in Pakistani Patients with Type 2 Diabetes Mellitus, Diabetes Obesity Metab., Vol. 6, 338-343 (2004).

22. R. CARMENA, P. DURIEZ and J.C. FRUCHART, Atherogenic Lipoprotein Particles in Atherosclerosis, Circulation, Vol. 109(23) Suppl 1, III2-7 (2004).

23. J.C. FRUCHART, M.C. NIERMAN, E.S. STROES, J.J. KASTELEIN, P. DURIEZ, New Risk Factors for Atherosclerosis and Patient Risk Assessment, Circulation, Vol. 109(23 Suppl 1):III15-9 (2004).

24. L.B. NIELSEN, Atherogenecity of Lipoprotein(a) and Oxidized Low Density Lipoprotein: Insight from in vivo Studies of Arterial Wall Influx, Degradation and Efflux, Atherosclerosis, Vol. 143, 229-243 (1999).

25. M.L. KOSCHINSKY, Lipoprotein(a) and the Link between Atherosclerosis and Thrombosis, Can. J. Cardiol., Vol. 2004 Suppl B, 37B-43B (2004).

26. D.L. EATON, W.J. KOHR, J.W. McLEAN, Q.-T. XU, C.J. MILLAR, R.M LAWN and A.M. SCANU, Partial Amino Acid Sequence of Apolipoprotein (a) Shows that it is Homologous to Plasminogen, Proc. Natl. Acad. Sci., Vol. 84, 3224-3228 (1987).

27. J.W. McLEAN, J.E. TOMLinsOn, D.-L. KUANG, D.L. EATON, E.Y. CHEN, G.M. FLESS, A.M. SCANU and R.M. LAWN, cDNA Sequence of Apolipoprotein (a) is Homologous to plasminogen, Nature, Vol. 330, 132-137 (1987).

28. V.J. MARDER and W.R. BELL, Fibrinolytic Therapy, in Haemostasis and Thrombosis. Basic Principles and Clinical Practice (R.W. COLMAN, J. HIRSH, V.J. MARDER, E.W. SALZMAN ed.), 2nd edn, pp. 1393-1437 (1989).

29. J.L. MILLER, A.J. KATZ and M.B. FEINSTEIN, Plasmin Inhibition of Thrombin-Induced Platelet Aggregation, Thromb. Diath. Haemorrh., Vol. 33, 286-309 (1975).

30. M.A. HANCOCK, M.B. BOFFA, S.M. MARCOVINA, M.E. NESHEIM and M.L. KOSCHINSKY, Inhibition of Plasminogen Activation by Lipoprotein(a): Critical Domains in Apolipoprotein(a) and Mechanism of Inhibition on Fibrin and Degraded Fibrin Surfaces, J. Biol. Chem., Vol. 278, 23260-23269 (2003).

31. R. TESTA and S.M. MARCOVINA, The Rate of Plasmin Formation after in vitro Clotting in Inversely Related to Lipoprotein (a) Levels, Intl. J. Lab. Clin. Res., Vol. 29, 128-132 (1999).

32. W.F. BAKER Jr., Thrombolytic Therapy, Clin. Appl. Thromb. Hemost., Vol. 8(4), 291-314 (2002).
33. V.J. MARDER and D. STEWART, Toward Safer Thrombolytic Therapy, Semin. Hematol., Vol. 39(3), 206-216 (2002).

34. D.E. BARRE, Lipoprotein (a) Reduces Platelet Aggregation via apo(a)-mediated Decreases in Thromboxane $\mathrm{A}_{2}$ Production, Platelets, Vol. 9(2), 93-96 (1998).

35. D.E. BARRE, Human Lipoprotein(a)-Induced Reduction of Platelet Aggregation is not Mediated by Apolipoprotein(a)'s Lysine Binding Regions, Frontiers in BioScience, Vol. 8, s12261228 (2003).

36. D.E. BARRE, Apolipoprotein (a) Mediates the Lipoprotein(a)Induced Biphasic Shift in Human Platelet Cyclic AMP, Thrombosis Research, Vol. 112, 321-324 (2003).

37. D.E. BARRE, Apoprotein (a) Antagonises the GPIIB/IIIA Receptor on Collagen- and ADP-stimulated Human Platelets, Fontiers in BioScience, Vol. 9, 404-410 (2004).

38. D.E. BARRE, Human Lipoprotein (a) is an Antagonist of Fibrinogen that Binds to the GPIIb (CD41) Protein on Agonist-Stimulated Human Platelets, J. Oleo Sci., Vol. 53, 305-308 (2004).

39. M.L. RAND, W. SANGRAR, M.A. HANCOCK, D.M. TAYLOR, S.M. MARCOVINA, S.M. MARCOVINA, M.A. PACKHAM et al., Apolipoprotein (a) Enhances Platelet Responses to the Thrombin Receptor-Activating Peptide SFLLRN, Arterioscler Thromb. Vasc. Biol., Vol. 18, 1393-1399 (1998).

40. C. MARTINEZ, J. RIVERA, S. LOYAU, J. CORRAL, R. GONZALEZ-CONEJERO, M.L. LOZANZO et al., Binding of Recombinant Apoprotein (a) to Human Platelets and Effect on Platelet Aggregation, Thromb. Haemost., Vol. 85, 686-693 (2001).

41. E. MALLE, A. IBOVNIK, H.J. LEIS, G.M. KOSTNER, P.F.J. VERHALLEN and W. SATTLER, Lysine Modification of LDL or Lipoprotein (a) by 4-hydroxyneal or Malondialdehyde Decreases Platelet Serotonin Secretion without Affecting Platelet Aggregability and Eicosanoid Formation, Arterioscler Thromb. Vasc. Biol., Vol. 15, 377-384 (1995).

42. C.H. MIELKE, M.M. KANESHIRE, I.A. MAHER et al., The Standarised Normal Ivy Bleeding Time and its Prolongation by Aspirin, Blood, Vol. 34, 204 (1969).

43. P. GRESELE, G. GUGLIELMINI, M. De ANGELIS, S. CIFERRI, M. CIOFETTA, E. FALCINELLI, C. LALLI, G. CIABATTONI, G. DAVI and G.B. BOLLI, Acute, Short-Term Hyperglycemia Enhances Shear Stress-Induced Platelet Activation in Patients with Type II Diabetes Mellitus, J. Am. Coll. Cadiol., Vol. 41, 1013-1020 (2003).

44. A. NOTARBARTOLO, G. DAVÌ, M. AVERNA, C.M. BARBAGALLO, A. GANCI, C. GIAMMARRESI, F.P. La PLACA and C. PATRONO, Inhibition of Thromboxane Biosynthesis and Platelet Function by Simvastatin in Type IIa Hypercholesterolemia, Arterioscler Thromb. Vasc. Biol., Vol. 15, 247-251 (1995).

45. P. NEEDLEMAN, M.O. WHITAKER, A. WYCHE, K. WATTERS, H. SPRECHER, A. RAZ, Manipulation of Platelet Aggregation by Prostaglandins and their Fatty Acid Precursors: Pharmacological Basis for a Therapeutic Approach, Prostaglandins, Vol. 19(1), 165-181 (1980). 